\title{
Application of Management Decision Virtual Simulation in Financial Forecasting of Thermal Power Plant
}

\author{
Shuliang Liu \\ School of Economics and Management \\ North China Electric Power University \\ Hebei, China
}

\author{
Yue Zhou* \\ School of Economics and Management \\ North China Electric Power University \\ Hebei, China
}

\begin{abstract}
The article takes the financial forecasting status of thermal power generation enterprises as the research background, applies the idea of virtual simulation of management decision to the financial forecast of thermal power enterprises, and realizes the simulation of future financial forecast of thermal power plant by designing simulation system and setting relevant rules. The virtual simulation results of management decision show that thermal power enterprises can survive and achieve sustainable development under the fierce competition environment.
\end{abstract}

Keywords-Virtual simulation of management decision; Financial forecast; Execution; Thermal power enterprise

\section{INTRODUCTION}

As a bridge connecting the market and enterprises, the financial activities of enterprises not only contain simple cash receipt and payment activities, but also include how to raise funds, how to invest and how to apply them to enterprises. In today's market environment, enterprises should not only pay attention to the use of funds, but also pay attention to the financing of funds and their daily control. It is very important for the future development of enterprises and even the operation of the whole social economy whether enterprises can reasonably predict their own funds and apply them to the appropriate scope. With the development of computer technology, operations research and other related fields, computer-based simulation systems have gradually emerged and further developed. Many managers apply this simulation technology to the operation and management of enterprises. By constructing a virtual operation platform, managers can predict and manage the future operation of enterprises, thus providing a basis for improving the quality of future decision-making. This virtual simulation aims to train participants to face multiple competitors in a changeable market environment, how to make better financial forecasts, and make corresponding enterprise decisions according to the forecast results, so as to better achieve enterprise goals.

Nowadays, thermal power enterprises are facing fierce market competition. The emergence of various new energy and clean energy makes the future development of thermal power enterprises worrying. In addition, the state constantly promulgates the "energy saving and emission reduction" policy, which makes the operation of thermal power enterprises facing difficulties. In this situation, it is very important for the future development of thermal power enterprises and the development of thermal power industry to make financial decisions on how to make financial prediction and properly forecast the three aspects of financing, investment and operation. Therefore, this paper takes the virtual simulation of management decisionmaking as the research method and applies it to the simulation of financial prediction of thermal power enterprises. It can not only simulate the future development environment of thermal power enterprises, but also make the financial prediction scheme formulated by participants more scientific and reasonable. It is of great significance to the future development of the entire industry.

\section{OVERVIEW OF VIRTUAL SimUlation OF MANAGEMENT DECISION}

Virtual simulation of management decision-making is a kind of role experience platform. Its design mainly refers to the enterprise resource planning system. The simulation platform system consists of six execution planes, representing six competing enterprises in the market [1]. Each execution plane chooses and sets the required functional centers according to the characteristics of the industry, such as Finance centers, production centers, logistics centers and marketing centers. Participants make their own financial decisions by simulating the operation of the enterprise and forecasting the future financial and market environment of the enterprise. In this process, financial forecasting is very important.

\section{FinANCIAL ForeCAST STATUS OF THERMAL POWER ENTERPRISES}

The famous scholar Simon once said that "management is decision-making", and the key of decision-making lies in prediction, which can be said to be the premise of decisionmaking. Enterprises in the market, if they cannot predict the development trend of the industry and their own financial needs, will eventually be eliminated by the market. In recent years, the electricity market has undergone tremendous changes. The former monopoly pattern has presented a competitive situation. With the gradual advancement of "bidding on the Internet", the power market competition faced by thermal power enterprises is becoming increasingly fierce. The marketization of coal price and the introduction of new 
energy such as wind power in 2018 make it difficult for thermal power enterprises to enter the electricity market. In this case, how thermal power enterprises change their business model, how to cope with the changes in future market and how to forecast their own financial needs become problems. For business managers to solve urgent issues, only by solving these issues can operators make better financial decisions. However, in the process of solving these problems, managers need experienced managers to carry out, but the experience comes from the practice of managers, and managers do not use uncertain risk and bankruptcy risk to make managers gain relevant experience, which makes the problem more difficult to solve.

Virtual simulation of management decision-making is a good simulation method for simulating the living environment and development status of future thermal power enterprises. It simulates the future development environment of thermal power enterprises with the unique advantages of execution, and provides a good platform for management to make financial prediction and improve decision-making ability.

\section{RULE DESIGN OF VIRTUAL SiMUlation FOR POWER Plant MANAGEMENT DECISION}

\section{A. Design of Execution Plane}

In the process of designing the execution plane of the financial prediction simulation system for thermal power enterprises, according to the actual operation situation of thermal power enterprises, the execution plane is divided into three centers to simulate, namely, the power production center, the business processing center and the financial center [3]. The specific composition and related functions of each center are detailed in TABLE I.

TABLE I. DESIGN OF EXECUTION SURFACE FOR THERMAL POWER ENTERPRISES

\begin{tabular}{|c|c|c|}
\hline $\begin{array}{c}\text { Center } \\
\text { category }\end{array}$ & Main function & Composition \\
\hline $\begin{array}{l}\text { Power } \\
\text { production } \\
\text { center }\end{array}$ & $\begin{array}{l}\text { Mainly responsible for the production of related power } \\
\text { products, the improvement of production efficiency, the } \\
\text { control of manufacturing costs, and the operation and } \\
\text { management of production equipment, including the } \\
\text { purchase of required raw materials, the renewal of units, } \\
\text { depreciation and scrapping. }\end{array}$ & $\begin{array}{l}\text { Generator set (with nine units and desulfurization equipment), coal (order and } \\
\text { inventory), fuel (order and inventory), materials (orders and inventory), water } \\
\text { (orders and inventory), and original value, depreciation and Impairment. }\end{array}$ \\
\hline $\begin{array}{l}\text { Business } \\
\text { processing } \\
\text { center }\end{array}$ & $\begin{array}{l}\text { Mainly responsible for related matters within the thermal } \\
\text { power enterprise, such as the payment of taxes and fees, } \\
\text { the payment of wages, the identification of related } \\
\text { certificates, etc. }\end{array}$ & $\begin{array}{l}\text { 300,000 production qualification certificate, 600,000 production qualification } \\
\text { certificate, } 1 \text { million production qualification certificate, ISO14000 certificate } \\
\text { (with four-year investment duration), ISO9000 certificate (with two-year } \\
\text { investment duration), desulfurization certificate (with two-year investment } \\
\text { duration), maintenance fee, wages and benefits, property insurance, sewage } \\
\text { charges, commissions, depreciation, other fees, management fees and taxes }\end{array}$ \\
\hline $\begin{array}{l}\text { Financial } \\
\text { center }\end{array}$ & $\begin{array}{l}\text { Mainly responsible for the overall financial planning and } \\
\text { control of thermal power enterprise. }\end{array}$ & $\begin{array}{l}\text { Cash, accounts receivable (divided into five types of one year, two years, three } \\
\text { years, four years and five years), accounts payable (divided into five types: one } \\
\text { year, two years, three years, four years and five years) Long-term loans (different } \\
\text { types from one to fifteen years), short-term loans, short-term interest, long-term } \\
\text { interest, and discounts. }\end{array}$ \\
\hline
\end{tabular}

\section{B. Rule Design of Market and Policy Environment}

In order to ensure the thermal power industry from the initial monopoly to the competitive situation and achieve the goal of energy saving and emission reduction, it is necessary to set up the market environment and policy environment for thermal power enterprises, which is an important guarantee to solve the financial forecasting problems faced by thermal power enterprises [6]. This paper realizes the transition from monopoly to competition through the formulation of electricity order rules. Specific market rules and policy rules are formulated as shown in TABLE II.

TABLE II. DESIGN OF MARKET AND POLICY RULES

\begin{tabular}{|c|c|}
\hline Rule category & Formulating principles \\
\hline \multirow{2}{*}{ Market rules } & The market environment gradually transitions from a complete monopoly to perfect competition. \\
& $\begin{array}{r}\text { - Capacity order-occupancy fell from } 100 \% \text { to } 0 . \\
\text { - Power Order-occupancy increased from 0 to } 100 \% .\end{array}$ \\
\hline \multirow{2}{*}{ Policy rules } & $\begin{array}{c}\text { Follow the policy of "Large pressure, energy saving and emission reduction" [5]. } \\
\text { - The standard coal consumption per kwh of a } 100,000 \mathrm{kw} \text { unit is } 450 \text { grams. } \\
\text { - The standard coal consumption per kwh of a } 1 \text { million kw unit is 270 grams. }\end{array}$ \\
\hline
\end{tabular}

\section{Rule Design of Power Bidding}

By setting up the bidding mode, the power market can be guaranteed from the initial monopoly to the realization of the competitive situation, and achieve the goal of energy saving and emission reduction. The setting of the rules in this link belongs to the realization of the market environment.
All power generation companies hold an annual power load subscription and bidding meeting. During the meeting, the power price of the power plant on the completion of desulfurization purchase and construction will be increased by 0.015 yuan. According to the policy, the electricity price is divided into capacity electricity price and electricity price [2]. The market share of these two prices was $60 \%$ and $40 \%$ respectively, and finally transitioned to a fully competitive 
market. In the bidding process of electricity price, the lowest price declared by the enterprise is the final execution price. The operators of each "simulation company" must follow the following procedures when making financial forecasts, decisions, and business operations management:

- Hold a new annual information gathering conference at the beginning of each year, and complete the formulation of the new annual plan and payment of the last year's enterprise income tax.

- According to the Interim Measures for the Administration of Electricity Price on the Internet issued by the National Development and Reform Commission, competing generators divide electricity price into capacity price and electricity price, in which capacity price is set by the government and electricity price is formed by market competition. Enterprise CEOs and CFOs participate in bidding online orders meeting. The demand for power load increases by $15 \%$ annually. CFOs are responsible for recording the detailed contents of the orders. In order to make the electricity price orderly after bidding, the price ceiling for bidding online is also stipulated- 0.471 yuan per kilowatt-hour.

- Long-term loans and short-term loans are selected according to the order status. Long-term loans are divided into five-year and ten-year loans and 20-year investment loans.

- After completing the loan, the CEO and CFO attend the coal purchase and order meeting, and the CFO is responsible for recording the order quantity.

- After the above-mentioned process is completed, the purchase of fuel, materials and water will begin. The purchase proportion of fuel oil is $1 \%$ of coal-fired cost, $3.5 \%$ of the material and $0.6 \%$ of coal-fired cost. After the purchase is completed, the storage of fuel, materials and water will be processed, and the units and requirements that need to be scrapped will be selected. Units to be invested.

- After the completion of the procurement process, the enterprise began to produce power products and deliver the final power products to customers.

- The financial center updates the relevant information of accounts payable and receivable according to the situation of payment and receivable, and makes the decision whether to invest in desulfurization and nitrate equipment, ISO9000 certificate and ISO14000 certificate. If the relevant investment decision has been made last year, only the corresponding amount will be paid this year.

- The financial center pays the principal and interest of short-term and long-term loans, power consumption fees, equipment maintenance fees, wages and welfare fees, property insurance fees, sewage discharge fees, commissioned operation fees, depreciation, other expenses, management fees, taxes and surcharges.
- After completing all the above activities, the financial center can carry out the process of closing accounts.

All the above-mentioned processes of managers must follow in the process of conducting a new round of financial forecasting.

\section{REALIZATION OF VIRTUAL SIMULATION FOR FINANCIAL FORECASTING}

Five to six personnel are responsible for the production, operation and financial management of thermal power enterprises [4]. This simulation personnel is the CEO, CFO, $\mathrm{CMO}, \mathrm{COO}$ and bidder of coal and electricity purchasing. In the actual simulation training, there are six groups of competing thermal power enterprises, all of which are 300 people. Referring to the above rules, the thermal power enterprises simulate their business activities for 15 years with bidding as the main competitive mode.

\section{SimULATION RESUlTS}

The simulation of thermal power financial forecast based on the rules formulated has been well realized. The actual simulation results show that the existence of competition factors will activate the enterprise's fighting spirit. In the fierce competition environment, thermal power enterprises can make the best use of everything and people, making good use of enterprise resources. In the competitive environment, enterprises not only make the cooperation ability of different teams within enterprises further exercised but also accumulate experience to deal with future market uncertainty risk, which lays a foundation for enterprises to achieve long-term and sustainable development.

\section{CONCLUSION}

In view of the related research of thermal power enterprises, more attention has been paid to the reduction of costs and the improvement of benefits, while the research on financial prediction of thermal power enterprises is relatively less. Based on this, this paper studies how thermal power enterprises can make financial prediction more effectively in the fiercely competitive environment by means of virtual simulation of management decision. It not only has the advantages of intuitive results and high participation, but also has the corresponding cost advantages. Enterprise managers can not only improve their professional quality, but also show and forecast the future development of thermal power industry by using simulation to carry out financial forecast and production activities.

\section{REFERENCES}

[1] Ying, Lv, Li Yuan, Yang, Yu, Liu. Study on Life Cycle Management of Project Integration Based on Sand Table Simulation[P]. Intelligent System Design and Engineering Applications (ISDEA), 2013 Third International Conference on,2013.

[2] Hu Hongju. Simple analysis of simulated operation and skills of enterprise sand table $[\mathrm{J}]$. Journal of Hebei Vocational College of Tourism, 2019 (02): 60-62. (In Chinese) 
[3] Lu Xinxin. Simulated Enterprise Management - Application of ERP Sand Table Training [J]. Economist, 2018 (03): 213-215. (In Chinese)

[4] Wang Bing, An Feng. Exploration on the teaching reform of ERP sand table simulation course based on the cultivation of College Students innovation and entrepreneurship ability [J]. Time Economics and Trade, 2019 (15): 56-57. (In Chinese)
[5] Li Ran, Cai Kaiwu. Reshaping the Training Teaching Objectives of Accounting Major in the Age of Artificial Intelligence: Taking the course of "Simulated Sand Table of Enterprise Management" as an example [J]. Forestry Teaching, 2019 (04): 37-39. (In Chinese)

[6] Zhao Mingfei. Exploration of Economics Sandbox Simulation Experiment Teaching[J]. Laboratory Research and Exploration,2018,37(11):281-285. (In Chinese) 